\title{
Editorial: Sounding Corporeality
}

\author{
AOIFE MCGRATH, MARCUS CHENG CHYE TAN, \\ PRARTHANA PURKAYASTHA AND TEREZA HAVELKOVÁ
}

This special issue emerges from a persistent set of questions often asked in both music and dance studies since a 'sonic turn' across a range of disciplines in the humanities, including theatre studies, at the beginning of the twenty-first century. ${ }^{1}$ What is the relationship between sound and body, corporeality and sonicity? How does sound interrelate and interact with the body and movement beyond the recognized effects of rhythm and affect? What are the frequencies through which bodies produce and receive sound, allowing for aesthetic and ethical practices of sounding, listening and hearing to emerge? What does a body-sound relationship mean and to whom, where and when - to different constituencies of people, to different cultural spaces and to different temporal locations? 'Sounding Corporeality' acknowledges and examines the intimate interactions, intersections and interventions of the aesthetic, the social and the political, to explore how corporeality sounds and how sonicity moves.

This special issue originated in a collaboration between two working groups of the International Federation of Theatre Research: the Choreography and Corporeality Working Group, and the Music Theatre Working Group. The interdisciplinary nature and global membership of both groups laid the foundation for this issue's collaborative, dialogic interrogation of sound and movement in performance. 'Sounding Corporeality' combines articles, a conversation essay and a curated dossier that gather scholarly and artistic voices from the US, Israel, Northern Ireland, Singapore, Italy, the UK, India and Australia. Practices featured in the articles and conversation essay range from US-based black improvisatory sound and choreography to the direction of Western opera, from the sonic embodiment in a practice-asresearch project in Northern Ireland, to an installation made in Taiwan, and from participatory performances in southern Italy focused on mass human migration in the Mediterranean to a sonic-visual installation paying homage to Vietnam's boat people and their traumatic migration across the South China Sea. The dossier contributions bring together a similar plurality of perspectives: sound and acoustics excavated from premodern amphitheatres, cave inscriptions, medieval Sanskrit texts and the field of folk performance in India; sound carried by an incapacitated, post-surgical body in Northern Ireland; and sounding/voicing by black and Asian dance and music artists/scholars that become scores and dialogues for new compositions, choreographies and practices of worldmaking. This gathering of plural voices was undertaken against the backdrop of a global pandemic and a renewed global awareness of ongoing racial inequality and oppression following the Black Lives Matter protests in 2020. In paying attention to the mobility of shared concerns, but 
also to distinctive social and political differences of the sonic-corporeal relationship across different cultural, racialized and gendered landscapes, this issue hopes to disturb and decolonize hegemonic understandings of movement and sound, and the coerced forms of stasis and silence these often take.

The relationship between the sonic and the haptic can be found in many musical cultures and genres: the human body in interaction with other bodies or physical objects produces sounds that are deeply entwined with the specific histories of place and space. ${ }^{2}$ Hearing or listening to sound and music may also resonate with the listener's motor system and enable embodied experiences of sounds which then in turn motivate them to move their own bodies. ${ }^{3}$ Our understanding of the relationship between music and the body has gradually been expanding beyond the increasingly nuanced understanding of the rhythmic and the gestural. In music scholarship, attention has been shifting from musical works and texts to musical practices and events, from music as a 'thing' to music as an activity - or what Christopher Small has famously called 'musicking'. ${ }^{4}$ This also includes increased awareness of the bodily aspects of music making, which concern not only performance and listening but also composition, long regarded within colonial paradigmatic thought as a purely privileged and intellectual activity of the West. Musical experience has been understood as inherently embodied and multimodal, involving senses other than hearing. Increased attention has been paid to the material aspects of musical performance, and to the fundamental relation between the musicking body and technicity, comprising not only media technology but also the different techniques and embodied mechanics of sound production. ${ }^{5}$ There has also been a growing awareness of how experiences of diverse bodies are shaped, articulated and shared through music and sound, including racialized and differently abled bodies. Recent approaches to the relationship between music and the body have also tried to bring together insights from science and the humanities, bridging the gap between musicology and neuroscience, cognitive and psychological studies, to recognize that 'our body is bio-socio-psycho-cultural'.

From a choreographic perspective, dance and music have traditionally been viewed as inextricably linked, with movement choreographed to, or improvised alongside, music that was either pre-existing or composed for its accompaniment. However, since the early twentieth century, many Western European and US-based dance practitioners and theorists have questioned this understanding of the sound-body relationship. Choreographers from expressionist dancer Mary Wigman in 1920s Germany to the Judson Dance Theatre collective in 1960s New York have argued for dance's independence from music, creating dances in silence, to the accompaniment of percussive or found sounds, or foregrounding the sounds made by the dancers' own bodies in movement. ${ }^{7}$ Pioneering multidisciplinary practitioners such as US composer and choreographer Meredith Monk have also expanded understanding of the intermedial relationship between the sonic and the corporeal, and possibilities for interweaving movement and sound composition. Recent theorizations on black sound and music also foreground the imbrication of the corporeal and the sonic that move beyond simplistic notions of sound as accompaniment to movement. In Sonic Bodies: 
Reggae Sound Systems, Performance Techniques, and Ways of Knowing (2011), Julian Henriques urges us to listen to the sound of the Jamaican dancehall on three wavebands: the material, the corporeal and the sociocultural. ${ }^{8}$ Henriques proposes that dancehall's sound system crew perform techniques of sounding where 'the logos of the MC's voicing is always triangulated with the ethos and pathos, that is, triangulated with the actual corporeal act of its enunciation'?

Drawing on interdisciplinary theories on black subjectivity and examining the sonic body's engagement with the politics of race, Thomas DeFrantz's article in this issue critically considers African American improvisatory practices within modalities of black dance. Analysing dancer and choreographer Dianne McIntyre's Sounds in Motion company and her choreographic philosophy, DeFrantz posits that improvisatory choice making by black artists can be regarded as embodied forms of resistance and survival, achieved through intermedial Africanist performance in ways that powerfully speak to Afro-pessimist thought and ontological bias. DeFrantz offers unique insights into how intermediality functions in McIntyre's body-sound interface, where performance has the oppositional capacity to 'affirm presence' within the confines of an everyday context of 'impossible citizenry' and a 'disavowed self.

A growing emphasis in recent scholarship on culturally situated bodies and voices has allowed for a recognition of aspects of vocal performance that have hitherto been underexamined, such as the racialization of vocal timbre as critically explored in Nina Sun Eidsheim's latest book, The Race of Sound: Listening, Timbre \& Vocality in African American Music. ${ }^{10}$ In opera studies, the relationship between voice and body has long been of crucial importance. Yet the operatic voice has often been conceptualized as disembodied, and tied up with notions of ephemerality and transcendence. Moreover, many scholars have pointed out a perceived discrepancy or outright split between voice and body in opera. ${ }^{11}$ Such theorizations tend to bypass the embodied materiality of actual singing performers. Michal Grover-Friedlander's article in this issue intervenes in the discussion on the body-voice relationship in opera by exploring the unique connection between a disembodied voice and sleepwalking feet with agency of their own, drawing a parallel between the culturally specific practices of Chinese foot binding and European castrato singing. As she points out, they are both forms of bodily mutilation that are aestheticized and eroticized. Concentrating on the opera The Empress's Feet by Evelyn Ficarra and Valerie Whittington (1995), Grover-Friedlander examines the 'liberating aspect' of the work and its performance, where a voice is given to the feet 'unbound'.

The disruptive and generative potential of the relationship between sonic and material bodies is also evident at the intersection of choreography and feminism in the work of practitioner-scholar Aoife McGrath, whose article examines her practice-as-research dance performance about social attitudes towards maternal labour, specifically breastfeeding, in Northern Ireland. McGrath's article chronicles the ways in which Let Down (2018) disturbed expected relations between sonic and corporeal aspects of maternal corporeality in performance. This uncoupling sought to make visible and audible the experiences of breastfeeding as a means of resisting the 'quietening' that has been imposed on maternal labour by many Western societies. In 
Let Down, two lactating women dance alongside a curated soundscape of live and recorded sounds that includes transposed sounds of breast pumps and live sounds of infants' cries and coos. McGrath mobilizes the methodological concept of 'quietening' to examine how a refiguring of intermedial relations between the sonic and the corporeal in performance can work to amplify the unheard, offering an alternative approach to the choreography of affective experience.

Attention to the material properties of sound also helps us to recognize its capacity to foster intersubjective relationships, which has been approached through the tropes of resonance and vibration, as explored in Nina Sun Eidsheim's Sensing Sound: Singing and Listening as Vibrational Practice (2015). ${ }^{12}$ Adopting Eidsheim's ideas that sound and music are vibrational experiences and sensations, Marcus Tan's article offers a material analysis of the interaction and interactivity between sound and movement, and their subjective reception. Written as a critical reflection, Tan analyses a Taiwanese experimental performance, Dear John (2017), a devised, intermodal choreomusical work that interprets John Cage's philosophies and notable works. Tan considers the ways in which sonification is an intermaterial vibrational process of bodily transmission and transformation. In relation to this intersubjective relation between sound and body, Tan ponders time as it is perceived and experienced in the performance and suggests that time is inherently sonic as sonicity is temporal.

Annalisa Piccirillo's contribution to this issue also attends to this notion of the embodied-sonic exchange as an intersubjective encounter when she discusses choreographic works that attend to aspects of human migration, including works addressing the so-called 'migrant crisis' on Mediterranean shores. Through an engagement with Jean-Luc Nancy's Listening (2007), and the concept of the re-sounding 'sonorous body' that encompasses a listening to resonances between 'self' and 'world', Piccirillo suggests that both body and sound can be considered as performative, migratory sites, and that in listening, or 'stretching the ear' towards the other, new possibilities for cohabitation and hospitality can be imagined. ${ }^{13}$

This special issue also contains reflections of artists on their own work, which offer unique perspectives on the interrelations between sonicity and corporeality in visual performance media. Prarthana Purkayastha converses with the internationally acclaimed Vietnamese-American-Japanese visual artist Jun Nguyen-Hatsushiba, exploring how his immersive works interrogate ocularcentrism in visual art through an interplay of sound, image and movement. Conferring specifically about the sound-film installation Memorial Project Nha Trang, Vietnam (2001), Nguyen-Hatsushiba reveals the aims and sociopolitical concerns framing his visual work and its sonic-corporeal dramaturgy, in which movement and sound offer anti-representational strategies of remembering Vietnam's collective trauma.

The curated 'Sound Moves' dossier brings together artists, scholars and curators involved in three separate collaborative projects - in India/Germany, Northern Ireland, and the UK/the USA/Australia - which speak in very diverse, yet interconnected, ways to this special issue's engagement with the sonic and the corporeal. The first dossier entry is focused on the 2020 A Slightly Curving Place exhibition held at the Haus der Kulturen der Welt (HKW) in Berlin. Here, curator 
Nida Ghouse (India) brought together a group of scholars and artists from Europe, the USA and India to respond to acoustic archaeologist Umashankar Manthravadi's practice of measuring the properties of sound in premodern amphitheatres in India. Tethered together by the overarching conceptual framework of listening to the past and its absence which remains', the contributions in this dossier feature the work of four artists/scholars from the Berlin exhibition: Umashankar Manthravadi discusses his interest in archiving sound, specifically the technology of ambisonics with which he listens to the acoustic properties of one of India's ancient amphitheatres at the Ranigumpha caves in Odisha. Moushumi Bhowmik offers reflections on the ethics of listening as she records the lived experiences of Bengali pallagaan song performers in Bangladesh. Alexander Keefe listens to the sonority of cave inscriptions and hears events of sounding and moving in Sanskrit verses. And finally, dancer-choreographer Padmini Chettur (with her collaborator, the composer Maarten Visser) listens to and re-creates the sound of movement in a premodern amphitheatre in Anupu (Andhra Pradesh), producing a sound-image study in the form of a two-channel video installation. Taken together, these pieces draw attention to technological, ethical, imaginative and embodied practices of listening to and recording sound, excavating and making visible and audible movement and sound from the past and the present of theatre, dance and performance.

In the second dossier contribution, 'Reassembled, Slightly Askew: Immersive Storytelling through Sound', five international artists based in Northern Ireland describe their collaborative 'relay' in creating an immersive work about playwright Shannon Yee's experience of suffering an acquired brain injury and subsequently learning to live with an invisible disability. In performance, Shannon's extraordinary corporeal journey is told entirely through sound, as hearing was her primary functioning sense during her recovery from brain surgery. Yet the creation of sound for the piece using binaural technology, and the audience's experience of it, are revealed to be deeply entwined in movement and the corporeal.

In the final dossier text, titled 'Unsettling Sound', Sara Jane Bailes and Arabella Stanger offer the 'at once destabilizing and liberatory' aspects of sounding, featured in a series of artist-scholar talks that they co-devised and hosted in autumn 2020 for Sussex Performance Events and Research (SPEAR) and the Attenborough Centre for the Creative Arts (ACCA) at the University of Sussex. The dossier's readers can 'listen' to a conversation on anti-racism and black lived experience between dancer-choreographers Alexandrina Hemsley, Seke Chimutengwende and sound designer Xana, which informs their online audio version of the choreography Black Holes (2018; excerpts of the audio show also feature here). In 'Building the Impossible Bridge' Rajni Shah and Royona Mitra, from their respective locations in Australia and the United Kingdom, sound out oppressive institutional structures through their voice notes, inviting audiences to listen to anti-racist artistic and scholarly practices of worldmaking. Finally, the award-winning African American composer and sound designer Jeremy Toussaint-Baptiste, known for engaging the sonic dimensions of black spaces, leaves readers with a new conceptual sound score. 
In The Audible Past (2003), Jonathan Sterne posits that 'a history of sound implies a history of the body. ${ }^{14}$ Sterne's verb choice is a curious one, for 'implies' provokes questions of the indicative relationship between sonicity and corporeality that is yet to be sufficiently mapped, even as the causalities and correlations of sound vis-à-vis movement are particularly well established. The discussions presented in this special issue are by no means comprehensive or definitive, but they invite further thoughts on the intricacies surrounding sonicity and corporeality, and about the combined expressive and communicative impact of sound and movement in theatre and performance studies.

NOTES

1 This special issue is in conversation with scholarship emanating from a renewed interest in auditory culture across the humanities at the beginning of the twenty-first century, which Tom McEnaney identifies as a 'sonic turn' precipitated by the publication of Emily Thompson's The Soundscape of Modernity (Cambridge, MA: MIT Press, 2002); and Jonathan Sterne's The Audible Past (Durham, NC: Duke University Press, 2003). See Tom McEnaney, 'The Sonic Turn', Diacritics, 47, 4 (2019), pp. 80-109. This sonic turn is also evident in the lively field of sound in theatre and performance studies, and the following selection of publications offers a snapshot of recent developments. For a discussion of the significance of the sonic turn in theatre see Adrian Curtin and David Roesner, 'Sounding Out "the Scenographic Turn”: Eight Position Statements', Theatre \& Performance Design, 1, 1 (2015), pp. 107-25. Marcus Tan offers a study of the soundscapes of intercultural performance through the examination of sound's performativity in Acoustic Interculturalisms: Listening to Performance (Houndmills: Palgrave, 2012), and MeLê Yamomo analyses sound histories in colonial South East Asia in Theatre and Music in Manila and the Asia Pacific, 1869-1946: Sounding Modernities (Basingstoke: Palgrave Macmillan, 2018). A discussion of avant-garde experiments with sound in Western Europe and the United States from the late nineteenth to the early twentieth centuries features in Adrian Curtin, Avant-Garde Theatre Sound: Staging Sonic Modernity (Basingstoke: Palgrave Macmillan, 2014); and Susan Bennet offers important theoretical insights on sound in Western theatre in Sound (London: Methuen Drama, 2019).

For instance, a collection of essays draws attention to the sound and movement nexus in South East Asia in Mohd Anis Md Nor and Kendra Stepputat, eds., Sounding the Dance, Moving the Music:

Choreomusicological Perspectives on Maritime Southeast Asian Performing Arts (London and New York: Routledge, 2017).

3 Clemens Wöllner, 'Introduction: Structured Sounds in Bodily and Spatial Dimensions', in Wöllner, ed., Body, Sound and Space in Music and Beyond: Multimodal Explorations (London and New York:

Routledge, 2018), pp. 1-10, esp. p. 1.

4 Christopher Small, Musicking: The Meanings of Performing and Listening (Middletown, CT: Wesleyan University Press, 1998). While the understanding of musical practices within their larger social and cultural contexts has been integral to the field of ethnomusicology, it has only gradually made its way into the study of Western music.

5 Operatic singing, for example, may be understood as a technology sui generis, due to the way the singer's body and voice amplify sound within the performance space of the opera house, as the result of a highly specialized vocal training. See Jonathan Sterne, 'Afterword: Opera, Media, Technicity', in Karen Henson, ed., Technology and the Diva: Sopranos, Opera, and Media from Romanticism to the Digital Age (Cambridge: Cambridge University Press, 2016), pp. 159-64, here p. 164.

6 Youn Kim and Sander L. Gilman, eds., The Oxford Handbook of Music and the Body (New York: Oxford University Press, 2019), p. 2.

7 See Stephanie Jordan, 'Choreographers and Musicians in Collaboration, from the Twentieth to the Twenty-First Century', in The Oxford Handbook of the Creative Process in Music, advance online version, 
114 mCgrath, tan, purkayastha and havelková Editorial: Sounding Corporeality

July 2018, at wwwoxfordhandbookscom.queens.ezp1.qub.ac.uk/view/10.1093/oxfordhb/9780190636197. o01.0001/oxfordhb-9780190636197-e-6?print=pdf (accessed March 2021).

Julian Henriques, Sonic Bodies: Reggae Sound Systems, Performance Techniques, and Ways of Knowing (New York: Continuum, 2011), pp. 22-7.

9 Ibid., p. 265, italics in original.

10 Nina Sun Eidsheim, The Race of Sound: Listening, Timbre \& Vocality in African American Music (Durham, NC: Duke University Press, 2019).

11 See, for example, Carolyn Abbate, 'Opera; or, the Envoicing of Women', in Ruth A. Solie, ed., Musicology and Difference: Gender and Sexuality in Music Scholarship (Berkeley, Los Angeles and London: University of California Press, 1993); and Jelena Novak, Postopera: Reinventing the Voice-Body (Farnham: Ashgate, 2015).

12 Nina Sun Eidsheim, Sensing Sound: Singing and Listening as Vibrational Practice (Durham, NC: Duke University Press, 2015).

13 Jean Luc Nancy, Listening (New York: Fordham University Press, 2007), p. 43.

14 Jonathan Sterne, The Audible Past: Cultural Origins of Sound Reproduction (Durham, NC: Duke University Press, 2003), p. 12, our italics. 